International

Medical Society

http://imedicalsociety.org

\title{
Nursing Diagnosis
}

\section{of Mothers and Roomed-In Newborns}

ORIGINAL

Simone Sousa Oliveira Fonseca” ${ }^{1}$ Maria Auxiliadora de Souza Gerk ${ }^{2}$, Marisa Dias Rolan Loureiro², Cristina Brandt Nunes ${ }^{2}$, Maria Lúcia Ivo², Lucyana Conceição Lemes Justino ${ }^{3}$, Isabelle Campos de Azevedo4, Marcos Antonio Ferreira Júnior ${ }^{4}$

\section{Abstract}

Objetivo: To identify the more frequent nursing diagnosis (ND) among mothers and newborns (NB) in a rooming-in accommodation, according to the taxonomy of the North American Nursing Diagnosis Association (NANDA) 2015-2017.

Method: This is a quantitative, cross-sectional, descriptive study in a Rooming-in Maternity of a University Hospital located in the Midwest region of Brazil, in the period from July to October 2013.

Results: The sample consisted of 101 mothers and their 102 newborn babies. There were 20 NDs identified among the mothers and nine ND among the newborns. The most common ND among the mothers were the risk of infection (96\%), impaired tissue integrity (96\%), impaired comfort (84\%) and willingness to improved breastfeeding (66\%); among the newborns ND there were the risk of infection $(100 \%)$ and the risk of imbalance of body temperature (100\%).

Conclusion: The identification of ND is essential for the work of nurses in rooming-in hospitals. It is expected that the results obtained in this research can contribute to the effectiveness of the NP in similar situations.

\section{Introduction}

Currently, nursing has focused on human responses defined by their personal experiences from the processes of health and disease, as well as through other experiences like birth, growth, development and human aging, considered phenomena of interest to the profession [1].

1 Regional Hospital Rosa Pedrossian, Campo Grande/MS, Brazil.

2 Federal University of Mato Grosso do Sul, Campo Grande/MS, Brazil.

3 Municipal Public Health Secretary, Campo Grande/MS, Brazil.

4 Federal University of Rio Grande do Norte, Natal/RN, Brazil.

\section{Contact information:}

\section{Marcos Antonio Ferreira Júnior.}

Address: Universidade Federal do Rio Grande do Norte, Centro de Ciências da Saúde, Departamento de Enfermagem. Avenida Salgado Filho, S/N, Lagoa Nova, Natal/RN, Brasil. CEP: 59078-970.

” marcos_nurse@hotmail.com

\section{Keywords}

Nursing Diagnosis; Postpartum

Period; Rooming-in Care; Infant Newborn; Nursing Care; Obstetric Nursing. 
One of the main areas of nurse's performance is the health care of women in their pregnancy and childbirth. This lifetime deserves special attention due to their emotional and physiologic changes. At this stage, the puerperal woman and her newborn (NB) require nursing care directed to these adaptations and require the use of the Nursing Process (NP) for the identification of the Nursing Diagnosis (ND) and planning of a personalized assistance [2].

The NP is a methodological instrument that enables to identify, understand, describe, explain and guide the needs of the person, the family or the human community at a given time of the health-disease process [3], in which the professional nursing care is needed [4]. The NP has five steps including research, nursing diagnosis, planning of the expected results, implementation, and evaluation of nursing care [5].

DE ND identification provides a systematic basis to choose nursing interventions that enable to achieve results the nurse is responsible [4], and to promote the language standardization between these professionals and to contribute to the technical and scientific advancement of the profession [6].

The NP includes the use of the diagnostic reasoning by the application of the clinical trial to identify problems for making decisions [7], and it requires knowledge, skills and experience of the specific area.

It is necessary to collect data through nursing history for the identification of ND, which consists of an interview and physical examination. The information collected require nurses' ability of perception and interpretation that can be examined, judged and synthesized [7].

It is up to the nurses to develop skills that will enable them to make clinical judgments regarding the nursing phenomena related to postpartum women and newborns, as well as using the ND [8] to plan the expected results, implementation of the assistance and carry out the nursing evaluation according to the health needs of each individual, individualized and personalized.
This study aimed to identify the most frequent nursing diagnosis among mothers and roomed-in newborns (NB) in a hospital according to the taxonomy of the North American Nursing Diagnosis Association (NANDA) 2015-2017 [9].

\section{Method}

This is a quantitative, cross-sectional, descriptive study, conducted in a rooming-in unit of a University Maternity Hospital, located in the Midwest region of Brazil, in the period from July to October 2013.

The Maternity in question has 20 beds for obstetrics care, eight of which are intended for clinical care and 12 beds for surgical care. In addition, the nursing team consists of 14 professionals, including two nurses, two techniques in nursing and 10 nursing assistants. Maternity makes up the state system of emergency care in hospital care of high risk, and is configured as municipal and state reference. His clientele comes from spontaneous and referred demand from other units of the Unified Health System, consisting mostly by teenage mothers, premature newborns and high-risk pregnancies.

The inclusion criteria for the composition of the sample were: postpartum women aged over 18 years old, being the third day after delivery, regardless of the type of delivery and medical diagnostics; and having a newborn of any gestational age who were exclusively in rooming-in mother company. Thus, indigenous newborns, maroon and medical diagnosis of disease were excluded, as well as indigenous mothers, maroon and those deprived of their liberty.

The data collection was performed by an interview and a physical examination, based on the Theory of Basic Human Needs of Wanda de Aguiar Horta [10] directed to puerperal mothers and newborns, both adapted of Gerk, Freitas and Nunes [11]. The interviews and physical examinations were performed on all mothers and newborns in the study. Also, the medical records were consulted completing necessary information in that records. 
Before the data collection, a pretest with 18 mothers and their newborns was performed to eliminate biases and adapt the instrument to the objective of the study and the research participants. These participants were included in the final research since the information collected met the criteria established in the method.

The collected variables related to mothers were: age, number of living children, marital status, education, work activities, psycho-spiritual needs, housing, sexuality, physiological needs, obstetric history and data from the current pregnancy. Related newborn: sex, birth weight, gestational age, Apgar score, sleep and rest and psychobiological needs.

Data were grouped and related according to the purpose of the study and then organized into information banks using Microsoft Office Excel ${ }^{\circledR}$ software 2010. The information characterization of puerperal and newborns was submitted to simple statistical analysis, with the establishment of absolute and relative frequencies.

The study was discussed with the participants and after reading the Consent and Informed (TCLE) and clarification of doubts, those who agreed to participate signed the consent form and subsequently data collection was initiated.

The research was submitted and approved in advance by the Ethics Committee Research on Human Beings of the Federal University of Mato Grosso do Sul (CEP /FMS), as recommended by Resolution CNS/MS 466/12 and approved by its ethical and methodological aspects in the opinion 248,439 of March 26, 2013, and CAE 14967813.6.0000.0021.

\section{Results}

The sample consisted of 101 mothers and their 102 newborns when there was a case of multiple births. There were 20 NDs identified among the mothers and nine ND among the studied newborns, as shown in Tables 2 and 3, respectively. The ND risk factors were defining characteristics (DC) and rela-
Table 1. Socio-demographic characterization of mothers assisted in Accommodation Maternity of the University Hospital Maria Aparecida Pedrossian. Campo Grande/MS, Brazil, in 2013 ( $n=101)$.

\begin{tabular}{|l|c|c|}
\multicolumn{1}{|c|}{ Variables } & $\mathbf{n}$ & $\%$ \\
\hline Age in years & & \\
\hline 18 the 19 & 26 & 25.4 \\
\hline 20 the 24 & 30 & 29.7 \\
\hline 25 the 29 & 23 & 22.7 \\
\hline 30 the 34 & 13 & 12.8 \\
\hline Marital status & & \\
\hline Married & 86 & 85.1 \\
\hline Single & 15 & 13.8 \\
\hline Employment status & & \\
\hline Jobless & 74 & 73.2 \\
\hline With work & 27 & 26.7 \\
\hline Family income in minimum wages & & \\
\hline$<1$ & 3 & 2.9 \\
\hline 1 the 3 & 87 & 86.1 \\
\hline 4 the 6 & 11 & 10.8 \\
\hline
\end{tabular}

ted factors (RF) that showed not less than $50 \%$ of the mothers and NBs [12]. For those who have not reached $50 \%$ frequency, it was decided to discuss the priority, involving patient safety, the interaction of a diagnosis with others and the need for nursing interventions [13]. Table 1 shows the socio-demographic data of the mothers. (Tables 2 \& 3)

Table 2. Nursing diagnosis identified among mothers. Campo Grande/MS, Brazil, in 2013 ( $n=101)$.

\begin{tabular}{|l|c|c|}
\hline \multicolumn{1}{|c|}{ Nursing Diagnosis* } & $\mathbf{n}$ & $\%$ \\
\hline Risk for infection & 96 & 95.0 \\
\hline Impaired tissue integrity & 96 & 95.0 \\
\hline comfort impaired & 84 & 83.1 \\
\hline Willingness to improved breastfeeding & 66 & 65.3 \\
\hline Poor knowledge & 32 & 31.6 \\
\hline Ineffective parenting process & 32 & 31.6 \\
\hline Risk for impaired maternity & 25 & 24.7 \\
\hline Dysfunctional family processes & 23 & 22.7 \\
\hline Constipation & 19 & 18.8 \\
\hline
\end{tabular}




\begin{tabular}{|l|c|c|}
\hline \multicolumn{1}{|c|}{ Nursing Diagnosis* } & $\mathbf{n}$ & $\%$ \\
\hline Acute pain & 18 & 17.8 \\
\hline Disturbed sleep pattern & 16 & 15.8 \\
\hline Risk for situational low self-esteem & 16 & 15.8 \\
\hline Risk for bond impaired & 12 & 12.9 \\
\hline Conflict in the role of mother & 11 & 10.8 \\
\hline Risk for ineffective parenting process & 10 & 9.9 \\
\hline Nutrition unbalanced more than body & 09 & 8.8 \\
\hline requirements & 08 & 7.8 \\
\hline Risk of mother-fetus bond disturbed & 08 & 7.8 \\
\hline Risk for impaired religiosity & 04 & 3.9 \\
\hline Risk for Unstable blood sugar & 03 & 2.9 \\
\hline Impaired skin integrity & & \\
\hline
\end{tabular}

*: More than one diagnosis per mother.

The DC, RF and risk factors were named according to NANDA taxonomy. Those not found in this classification were added based on clinical judgment grounded in the literature of gynecology and obstetrics [5].

The most common ND among them was a risk for infection with 96 (95\%), impaired tissue integrity
Table 3. Nursing diagnosis identified among newborns. Campo Grande/MS, Brazil, in 2013 $(n=102)$

\begin{tabular}{|l|c|c|}
\hline \multicolumn{1}{|c|}{ Nursing Diagnosis* } & $\mathbf{n}$ & $\%$ \\
\hline Risk for infection & 102 & 100 \\
\hline Risk for imbalance in body temperature & 102 & 100 \\
\hline Risk for Neonatal jaundice & 41 & 40.1 \\
\hline Ineffective breastfeeding & 36 & 35.6 \\
\hline Risk of bond impaired & 15 & 14.7 \\
\hline Risk and impaired skin integrity & 10 & 9.8 \\
\hline Risk of unstable blood sugar & 04 & 3.9 \\
\hline Interrupted breastfeeding & 04 & 3.9 \\
\hline Risk for constipation *: More than one diagnosis per NB. & 02 & 1.9 \\
\hline
\end{tabular}

with 96 (95\%), impaired comfort with 84 (83\%) and willingness to improved breastfeeding with 66 (65\%). The DC, the RF and the risk factors identified more frequently to these ND are shown in Table 4.

As for the $\mathrm{Nb}, 58$ (57\%) were born with complete gestation, and 98 (97\%) weighing at least $2500 \mathrm{~g}$. The most frequent ND was the risk for infection

Table 4. Nursing diagnosis, risk factors, defining characteristics and more frequent related factors among mothers. Campo Grande/MS, 2013 ( $\mathrm{n}=101)$.

\begin{tabular}{|c|c|c|c|c|c|}
\hline Nursing Diagnosis & n & $\%$ & Risk factors/defining characteristics/related factors & n & $\%$ \\
\hline \multirow[t]{3}{*}{ Risk for infection } & \multirow[t]{3}{*}{96} & \multirow[t]{3}{*}{100} & Environmental exposure to increased pathogens. & 96 & 100 \\
\hline & & & Invasive procedures. & 96 & 100 \\
\hline & & & Alteration in skin integrity. & 84 & 83 \\
\hline \multirow[t]{2}{*}{ Impaired tissue integrity } & \multirow[t]{2}{*}{96} & \multirow[t]{2}{*}{95} & Defining characteristics & & \\
\hline & & & Injured subcutaneous tissue. & 96 & 100 \\
\hline \multirow[t]{7}{*}{ Impaired comfort } & \multirow[t]{7}{*}{84} & \multirow[t]{7}{*}{83} & Related factors & & \\
\hline & & & Invasive procedures. & 83 & 86 \\
\hline & & & Surgery procedures (cesarean section). & 63 & 66 \\
\hline & & & Defining characteristics & & \\
\hline & & & Discomfort with the situation. & 45 & 54 \\
\hline & & & Related factors & & \\
\hline & & & Episiotomy/episiorrhaphy. & 28 & 33 \\
\hline \multirow{4}{*}{$\begin{array}{l}\text { Willingness to improved } \\
\text { breastfeeding }\end{array}$} & \multirow[t]{4}{*}{66} & \multirow[t]{4}{*}{65} & Defining characteristics & & \\
\hline & & & The mother puts the NB in her chest to promote a successful catch & 52 & 79 \\
\hline & & & Related factors & & \\
\hline & & & Adequate breast structure. & 49 & 74 \\
\hline
\end{tabular}


Table 5. Nursing diagnosis and more frequent risk factors among newborns. Campo Grande/MS, 2013 $(n=102)$.

\begin{tabular}{|c|c|c|c|c|c|}
\hline Nursing Diagnosis & n & $\%$ & Risk factors & n & $\%$ \\
\hline \multirow[t]{2}{*}{ Risk for infection } & 102 & 100 & Inadequate primary defense. & 102 & 100 \\
\hline & & & Increased environmental exposure to pathogens. & 102 & 100 \\
\hline Risk for imbalance in body temperature & 102 & 100 & Extreme age & 102 & 100 \\
\hline
\end{tabular}

and risk for the imbalance in body temperature. Risk factors most commonly found associated with the ND are shown in Table 5.

\section{Discussion}

The most common risk factors among mothers with a diagnosis of risk for infection were increased environmental exposure to the pathogen (100\%), invasive procedures (100\%) and broken skin (83\%) related to the surgery (cesarean section), episiotomy and episiorrhaphy. The ND of risk for infection was the most frequent among women hospitalized in specialized hospital sectors [14]. The risk factor found in all mothers at risk for infection was the increased environmental exposure to pathogens, due to its hospital environment that favors exposure to microorganisms and physiological changes inherent in the puerperal period.

During pregnancy and puerperal period, the woman have significant changes in her body that make her susceptible to acquiring infections, particularly when there is blood loss postpartum of more than $1,000 \mathrm{ml}$ and experiencing premature rupture of membranes, prolonged labor, malnutrition or obesity, excessive vaginal manipulation, surgical trauma, poor aseptic procedures, cesarean delivery, immune weakness and retention of ovular remains [15].

The second and third risk factors found in 100\% and $87.5 \%$ of mothers with the ND of risk for infection were invasive procedures and change in skin integrity, respectively, related to venipuncture, the bladder catheterization and surgical incision of the cesarean section that it was held in $66 \%$ of the women in the study. There were $38 \%$ of mothers giving birth by low via and $74 \%$ of them were submitted to episiotomy and episiorrhaphy.

It was observed that despite the recommendations of the Ministry of Health of Brazil [16], through policies aimed at reducing the high rates of unnecessary caesarean, these amounts are still a significant portion of total births, as reflected in this study. The World Health Organization established a Caesarean section rate of $10 \%$ to $15 \%$ as ideal based on the precept that only $15 \%$ of total deliveries present indication for this intervention. [17]

The most frequent DC for the ND of Impaired tissue integrity was the Injured subcutaneous tissue $(100 \%)$ of the mothers, and the RF were invasive procedures (86\%) and surgical procedure for cesarean section (66\%).

The ND of impaired tissue integrity is one of the most factors identified among mothers [14, 18]. Lesions of vaginal and perineal tissues, episiotomy, abdominal incision, breast engorgement and nipple fissures are very common factors associated with such events [18]. Despite the scientific evidence, procedures such as episiotomies and episiorrhaphy are performed routinely, and this practice exposes the risk for infection to the puerperal, as demonstrated by this study.

Every year in Brazil, there are 1.5 million women given birth by vaginal delivery and most of them suffer some perineal trauma, either by episiotomy or spontaneous lacerations, which expose the morbidities associated with these traumas, such as perineal pain and bleeding. In many of these deliveries, perineal trauma sometimes is sutured without good visualization of the site, with the risk of causing accidents and injuries in the genitourinary tract and 
the structures of the pelvic floor, which can increase the risk for infection [19].

A study conducted in the 1980s to reassess the routine performance of episiotomy analyzed more than 350 articles and books and concluded that there was insufficient evidence to be routinely recommended [20]. From this publication, numerous studies of systematic review, meta-analyses and randomized clinical trials have been undertaken in several countries to expose the need for a strict decrease in this practice [21].

The Brazilian Ministry of Health does not recommend a routine episiotomy [22]. It is one of the only procedures performed without the prior consent of the patients [23], which were fully informed of the benefits and risks during the prenatal visits or antepartum period, probably they did not consent to their implementation [21].

The episiotomy performed selectively when compared to the routine in vaginal deliveries is significantly associated with lower risk of posterior perineal trauma, reducing the need for suturing, minimizing complications in healing and decreasing bleeding $[22,25]$. As a disadvantage, there is an increased risk of perineal trauma [24], although the anterior perineal trauma is less painful than the posterior perineal trauma when occurred [25].

A study conducted in Portugal revealed that among women who underwent episiotomy and those who had spontaneous lacerations, there was a significantly higher incidence of infection among the women with a spontaneous laceration. These data show that spontaneous laceration is less harmful to the perineal tissues and the woman since the episiotomy is a second-degree injury [23].

For the ND of impaired comfort, the DC with the highest frequency was the reported discomfort with the situation (54\%) and factors related to it in 33\% of cases were episiotomy and episiorrhaphy. Again, these procedures were identified as factors related to others diagnostic and pointed to the routine performance of these procedures in the study setting, as well as represent the disadvantages of routine episiotomy in vaginal labor.

The DC identified as frequent for the ND of willingness to improved breastfeeding was the mother can put the baby on her chest to promote a successful catches (79\%) and the most frequent RF was adequate breast structure (74\%), which refers the protruding nipples that facilitate the NB catching the breast and the effective suction. [25] This same ND has been identified in other studies, called as effective breastfeeding [7, 14, 27]. This DC and RF were also found in another study with similar results [7].

The positioning and incorrect catching of the baby can cause problems, such as insufficient emptying of the breast or milk stasis, with consequent obstruction of ducts, milk ejection difficult and traumatized nipples occur [28].

As for the NB, the ND present in all subjects of the sample were a risk for infection and risk for the imbalance in body temperature. These are ND of the risk of a future order, which may or may not occurs depending on the actions of promotion of health and disease prevention to be implemented by the nurse.

The risk factors highlighted in this study were inadequate primary defense and increased environmental exposure to pathogens identified in 100\% of babies who due to their low immunity are more prone and exposed to some infection. In a study of a rooming-in public hospital located in the northeast of Brazil the same risk factors in all infants studied were found [27].

It must be considered that neonates are subject to infection due to the transition of the sterile uterine medium to the contaminated environment. Also, the biological fragility and immaturity of many systems, especially the immune have to be considered [28].

Besides the above, there is a risk of the umbilical stump handling infection without proper hand hygiene and use of contraindicated substances for 
their antiseptic, since it is a gelatinous structure that dehydrates gradually after birth until it is completely mummified, ready for falling [29].

The ND of the risk of imbalance in body temperature was also found in all newborns and the risk factor associated with extreme age. The NB loses heat by evaporation, conduction, convection and radiation. At birth, the thermoregulation mechanism is immature [30], and the newborn loses heat rapidly to the external environment, so his care of body temperature should be initiated in the delivery room. In extreme temperature conditions, the NB is hampered by the physical inability to maintain homeostasis [31]. Thus, the care of the control and maintenance of body temperature of the neonate are important to his survival.

NBs are more susceptible to contracting infections, since the lower the gestational age, the higher immaturity of their organs, especially the skin [31]. The care thermoregulation and skin are essential during the neonatal period.

\section{Conclusions}

In this study, the most frequent ND was identified among mothers and their roomed-in newborns, their $D C$, their RF and risk factors. The most frequent ND among postpartum women were Risk for infection, Impaired tissue integrity, Impaired comfort, Willingness to improved breastfeeding, among others. In newborns it was identified Risk for infection, Risk for imbalance in body temperature, among others. Determining the ND is essential for the planning of care, because when performing their prescriptions, nurses should direct them to related factors and risk to address the causes associated with the identified problems.

From the ND identification, it is the possible plan the nursing care for mothers and their newborns to ensure the health promotion and disease prevention during pregnancy and puerperal period and neonatal rooming-in.
It is expected that the results obtained in this research can contribute to the effectiveness of the NP in other realities. However, there are limitations that the results show the reality of a single maternity. However, such studies are still scarce in the context of the Midwest region of Brazil. Research are needed to enable the development of nursing interventions to this population in the same conditions.

\section{References}

1. Doenges ME, Moorhouse MF. Application of Nursing Process and Nursing Diagnosis: na interative text for diagnostic reasoning. 6 ${ }^{\text {a }}$ ed. Philadelphia: F. A. Davis Company, 2013.

2. Nery IS, Santos AG, Sampaio MRFB. Dificuldades para a implantação sistematização da assistência de enfermagem em maternidades. Enfermagem em Foco. 2013; 4(1):11-4. Available from: http://revista.portalcofen.gov.br/index.php/enfermagem/ article/download/494/184

3. Garcia TR, Nóbrega MML. Processo de enfermagem: da teoria à prática assistencial e de pesquisa. Esc Anna Nery Rev Enferm. 2009; 13(1):188-193. Available from: http://www.scielo.br/pdf/ ean/v13n1/v13n1a26.pdf

4. Avena MJ, Pedreira MLG, Gutiérrez MGR. Conceptual validation of the defining characteristics of respiratory nursing diagnoses in neonates. Acta Paul Enferm. 2014; 27(1):76-85. Available from: $\quad$ http://www.scielo.br/pdf/ape/v27n1/pt 0103-2100ape-27-01-00076.pdf

5. Tannure MC, Pinheiro AM. Sistematização da Assistência de Enfermagem: guia prático. $2^{\mathrm{a}}$ ed. Rio de Janeiro (RJ): Guanabara Koogan, 2013.

6. Bousso RS, Poles K, Cruz DALM. Nursing concepts and theories. Rev Esc Enferm USP. 2014; 48(1):144-8. Available from: http://www.scielo.br/pdf/reeusp/v48n1/pt 0080-6234reeusp-48-01-141.pdf

7. Lunney M. Diagnóstico de Enfermagem, pensamento e pensamento crítico. In: Lunney $M$. Pensamento crítico e diagnósticos de enfermagem: estudos de caso e análises. Porto Alegre: Artmed; 2004, p. 21-38.

8. Silva EP, Alves AR, Macedo ARM, Bezerra RMSB, de Almeida PC, Chaves EMC. Nursing diagnoses related to breastfeeding in a rooming-in unit. Rev Bras Enferm. 2013; 66(2):190-5. Available from: http://www.scielo.br/pdf/reben/v66n2/06.pdf

9. Diagnósticos de enfermagem da NANDA: definições e classificação 2015-2017/NANDA Internacional. Tradução de Regina Machado Garcez. Porto Alegre: Artmed, 2015.

10. Horta WA. Processo de enfermagem. São Paulo: EPU-EDUSP, 1979.

11. Gerk MAS, Freitas SLF, Nunes $C B$. Introdução à sistematização da assistência de enfermagem. In: Baston H, Hall J (Org.). Uma abordagem humanizada: pós-parto. Rio de Janeiro: Elsevier, 2010. 
12. Silva APAS. Violência entre adolescentes por armas de fogo e brancas - morbimortalidade, necessidades básicas e assistência hospitalar [tese]. Universidade Federal de Mato Grosso do Sul, Programa de Pós-graduação em Saúde e Desenvolvimento, Campo Grande (MS). 2012. Available from: https://sistemas. ufms.br/sigpos/portal/trabalhos/download/684/cursold:88

13. Lunney M. Princípios orientadores para uso de diagnósticos $e$ enfermagem, da NANDA-I, da NOC e da NIC. In: Lunney M. et al. Pensamento crítico para o alcance de resultados positivos em saúde: análises e estudos de caso em enfermagem. Porto Alegre: Artmed; 2011, p. 57-70.

14. Vieira F, Bachion MM, Salge AKM, Munari DB. Nursing Diagnosis NANDA in Puerperium at the immediate and late. Esc Anna Nery Rev Enferm. 2010; 14(1):83-9. Available from: http://www. scielo.br/pdf/ean/v14n1/v14n1a13.pdf

15. Benincasa BC, Walker C, Cioba C, Rosa CCS, Martins D, Dias E et al. Taxas de Infecção relacionados a partos cesáreos e normais no hospital e Clínicas de Porto Alegre. Rev HCPA. 2012;32(1):59. Available from: http://seer.ufrgs.br/index.php/hcpa/article/ download/24094/16455

16. Brasil. Ministério da Saúde. Pré-natal e puerpério: atenção qualificada e humanizada: manual técnico. Brasília (DF): Ministério da Saúde, 2006. Available from: http://bvsms.saude. gov.br/bvs/publicacoes/manual pre natal puerperio 3ed.pdf

17. Mendonza-Sassi RA, Cesar JA, Silva PR, Denardin G, Rodrigues MM. Risk factors for cesarean section by category of health service. Rev Saúde Pública 2010; 44(1):80-9. Available from: http://www.scielo.br/pdf/rsp/v44n1/09.pdf

18. Silva AFD, Nóbrega MMLD, Macedo WCMD. Nursing diagnoses/ outcomes for parturient and puerperal women using the International Classification for Nursing Practice. Rev. Eletr. Enf. 2012; 14(2):267-76. Available from: http://dx.doi.org/10.5216/ ree.v14i2.11211

19. Riesgo MLG, Costa ASC, Almeida SFS, Basile ALO, Oliveira SMJV. Episiotomy, laceration and perineal integrity in spontaneous deliveries: analysis of factors associated. Rev. enferm. UERJ, Rio de Janeiro, 2011; 19(1):77-83. Available from: http://www. facenf.uerj.br/v19n1/v19n1a13.pdf

20. Thacker SB, Banta HD. Benefits and risks of episiotomy: An interpretive review of the English language literature, 18601980. Obstet Gynecol Surv. 1983; 38(6):322-38. Available from: http://www.ncbi.nlm.nih.gov/pubmed/6346168

21. Carvalho CCM, Souza ASR, Moraes Filho OB. Episiotomia seletiva: avanços baseados em evidências. Femina. 2010; 38(5):265-70. Available from: http://files.bvs.br/upload/s/0100-7254/2010/ v38n5/a008.pdf

22. Brasil. Ministério da Saúde. Parto, aborto e puerpério: assistência humanizada à mulher. Brasília (DF): Ministério da Saúde, 2001.

23. Borges BB, Serrano F, Pereira F. Episiotomia: uso generalizado versus selectivo. Acta Médica Portuquesa. 2003; 16(6):447454. Available from: http://repositorio.chlc.min-saude.pt/ bitstream/10400.17/1796/1/AMP\%202003\%20447.pdf

24. Carroli G, Mignini L. Epiotomy for vaginal birth. Cochrane Database Syst Rev. 2009; 21(1). Available from: http://www. ncbi.nlm.nih.gov/pubmed/19160176
25. Mattar R, Aquino MMA, Mesquita MRS. The practice of episiotomy in Brazil. Rev Bras Ginecol Obstet. 2007; 29(1):1-2. Available from: http://www.scielo.br/pdf/rbgo/v29n1/a01v29n1

26. Abrão ACFV, Gutiérrez MGR, Marin HF. The ineffective breastfeeding nursing diagnosis-study of the identification and clinical validation. Acta Paul Enferm 2005; 18(1):46-55. Available from: http://www.scielo.br/pdf/ape/v18n1/a07v18n1.pdf

27. Inácio CCN, Chaves EMC, Freitas MC, Silva AVS, Alves AR, Monteiro AR. Nursing diagnoses in in-rooming units. Rev Bras Enferm. 2010; 63(6):894-9. Available from: http://www.scielo. br/pdf/reben/v63n6/04.pdf

28. Del'Angelo N, Góes FSN, Dalri MCB, Leite AM, Furtado MCC, Scochi CGS. Nursing diagnoses of premature infant under intermediary care. Rev Bras Enferm. 2010; 63(5):755-61. Available from: http://www.scielo.br/pdf/reben/v63n5/10.pdf

29. Linhares EF, Silva LWS, Nunes ECDA, Martins LA, Cerqueira DZ. Desvelando saberes empírico-científicos nas ações extensionistas de cuidado ao recém-nato e família. Conexão UEPG. 2011; 7(2):222-9. Available from: http://www.revistas2. uepg.br/index.php/conexao/article/view/3720/2609

30. Amante LN, Slomochenski LA, Teixeira MGPN, Bertoncello KCG. Occurrence of Unplanned Hypothermia in Post-Anesthesia Recovery Room. UNOPAR Cient, Ciênc Biol Saúde. 2012; 14(4). Available from: http://revistas.unopar.br/index.php/biologicas/ article/download/424/410

31. Rolim KMC, Linhares DC, Rabelo LS, Gurgel EPP, Magalhães FJ, Caetano JA. Care with premature newborn's skin in a neonatal intensive care unit: nurse's knowledge. Rev. Rene. 2008; 9(4):107-15. Available from: http://www.redalyc.org/ pdf/3240/324027964013.pdf

\section{Publish in International Archives of Medicine}

International Archives of Medicine is an open access journal publishing articles encompassing all aspects of medical science and clinical practice. IAM is considered a megajournal with independent sections on all areas of medicine. IAM is a really international journal with authors and board members from all around the world. The journal is widely indexed and classified Q2 in category Medicine. 